\title{
A PROSPECTIVE OBSERVATIONAL STUDY ON PREDICTION OF PREECLAMPSIA IN EARLY PREGNANCY BY SPOT URINE PROTEIN-CREATININE RATIO
}

\author{
Sabari Kasinathan ${ }^{1}$, Nithiya Subbaiyan ${ }^{2}$ \\ ${ }^{1}$ Consultant, KRK Clinic, Gandhi Nagar, Viruthachalam, Tamilnadu, India. \\ ${ }^{2}$ Assistant Professor, Department of Obstetrics and Gynaecology, Government Villupuram Medical College and Hospital, Villupuram, \\ Tamilnadu, India.
}

\section{ABSTRACT}

\section{BACKGROUND}

Hypertension and proteinuria are minimum criteria to diagnose preeclampsia. Proteinuria is called significant when there is excretion of more than or equal to $300 \mathrm{mg}$ of urinary protein in $24 \mathrm{hrs}$. period. Even though $24 \mathrm{hrs}$. urine collection is the Gold standard for the diagnosis of significant proteinuria. Spot urine protein-creatinine ratio is a more rapid and convenient method to detect protein excretion.(1) Therefore, prediction of preeclampsia in early gestation is of utmost importance to detect and to intervene in the management of high-risk pregnancies much earlier to reduce the maternal death and foetal mortality and neonatal morbidity.(2)

\section{MATERIALS AND METHODS}

A prospective observational study was conducted during the period of January 2013 to November 2013. Women with 16 to 20 wks of gestation with singleton pregnancy, both Primi and Multigravida were included. A total number of 300 antenatal women who attended the antenatal clinic in the Department of Obstetrics and Gynaecology at Kilpauk Medical College. They were selected according to inclusion and exclusion criteria. Patient's urine sample was collected and protein-creatinine ratio was estimated. Protein estimation was done using pyrogallol method. Creatinine estimation was done by modified Jaffe's method and the ratio was obtained between the two. Patients were advised to attend the antenatal clinic every two weeks. In her follow-up visit she was examined thoroughly, especially her blood pressure and urine albumin was checked. Foetal well-being was assessed at each visit.

\section{RESULTS}

When age group was taken into consideration, about $42.9 \%$ developed preeclampsia and $5 \%$ did not develop preeclampsia in the age group $<20$ years. In the age group $>30$ years, $38.1 \%$ developed preeclampsia and $7.9 \%$ did not develop preeclampsia. There was statistical significance between normal cohort and preeclamptic cohort. In my study, about $81 \%$ preeclampsia occurred in primigravida and only $4.8 \%$ occurred in gravida 2 and gravida 3 . About $9.5 \%$ of preeclamptic cohort and $2.2 \%$ of normal cohort were present among gravida 4. Among the people belonging to SE class 5, about $76.2 \%$ developed preeclampsia and $23.8 \%$ belonged to preeclamptic cohort in women belonging to SE class 4 . There is no statistical significance with regard to SE class. About $47.6 \%$ of preeclamptic cohort were moderately obese patients. In my study group, preeclampsia did not occur in underweight persons. Only 9.5\% of preeclampsia occurred in women with normal BMI and 33.3\% in overweight individual. The variable BMI is also statistically significant. The cut-off value for urine PCR was taken as $>0.45$, to predict preeclampsia with $85.71 \%$ sensitivity and $99.64 \%$ specificity. When the cut-off value is reduced, the sensitivity increases. The area under the ROC curve for urine PCR is 0.964 .

\section{CONCLUSION}

After analysing the study, it was found that urine spot PCR is a simple method and rapid test to predict preeclampsia. From this study, it was found that when the cut-off value for urine spot PCR was $>0.45$, the sensitivity was $85.71 \%$ and specificity was $99.64 \%$. When the cut-off value is more, the specificity increases. It was also found that more number of preeclampsia occurred in women with increased pre-pregnant weight with increased BMI. Therefore, proper weight reduction will reduce the risk of developing preeclampsia. Urine spot PCR can be used to predict preeclampsia with a single random midstream urine sample when compared to $24 \mathrm{hrs}$. urine-protein estimation and routine dipstick method. Urine spot PCR can be used to predict preeclampsia in early gestation itself, so that the patient can be kept under proper surveillance with more frequent antenatal check-up and to detect the complications earlier to prevent maternal and foetal morbidity and mortality.

\section{KEY WORDS}

Hypertension, Preeclampsia, Spot Test.

HOW TO CITE THIS ARTICLE: Kasinathan S, Subbaiyan N. A prospective observational study on prediction of preeclampsia in early pregnancy by spot urine protein-creatinine ratio. J. Evolution Med. Dent. Sci. 2018;7(22):2702-2708, D0I: $10.14260 /$ jemds/2018/609

'Financial or Other Competing Interest': None.

Submission 06-04-2018, Peer Review 15-05-2018,

Acceptance 21-05-2018, Published 28-05-2018.

Corresponding Author:

Nithiya Subbaiyan,

No. 1/177, Lakshmi Nagar, Maharajapuram,

East Pondy Road, Villupuram-605602.

E-mail: drsnithiya99@gmail.com

DOI: $10.14260 /$ jemds $/ 2018 / 609$

\begin{abstract}
BACKGROUND
Hypertensive disorders complicates about 5\% - 10\% of pregnancies. It is the third most common causes for maternal and foetal morbidity and mortality.(3) It is one among the triads, which causes maternal mortality like that of haemorrhage and infection. Hypertension and proteinuria are minimum criteria to diagnose preeclampsia. Proteinuria is called significant when there is excretion of more than or equal to $300 \mathrm{mg}$ of urinary protein in $24 \mathrm{hrs}$. period.(3)
\end{abstract}


Proteinuria is a marker that indicates system wide endothelial leaks. Abnormalities in the angiogenic balance play an important role in the cascade of events leading to protein excretion, hypertension and endothelial dysfunction.(4)

Even though 24 hrs. urine collection is the Gold standard for the diagnosis of significant proteinuria. Spot urine protein-creatinine ratio is a more rapid and convenient method to detect protein excretion.(1) It avoids the influence of variations in urinary solute concentration. Therefore, it is an accurate test and provides efficient in-patient and outpatient monitoring. (5)

Berg and Colleagues (2003) reported that about $16 \%$ of maternal deaths are due to complications related to preeclampsia and more than half of it are preventable.(6)

Therefore, prediction of preeclampsia in early gestation is of utmost importance to detect and to intervene in the management of high-risk pregnancies much earlier to reduce the maternal death and foetal mortality and neonatal morbidity.(7)

Prediction of preeclampsia by spot urinary ProteinCreatinine ratio in early pregnancy [Before 20 weeks of pregnancy]. In this study, we find the maternal outcome in developing Preeclampsia and Eclampsia.

\section{MATERIALS AND METHODS}

This prospective observational study was done during the period of January 2013 to November 2013. Our study included a total number of 300 antenatal women who attended the antenatal clinic in the Department of Obstetrics and Gynaecology at Kilpauk Medical College. They were selected according to inclusion and exclusion criteria.

\section{Inclusion Criteria}

Women with 16 to 20 wks of gestation with singleton pregnancy, both Primi and Multigravida.

\section{Exclusion Criteria}

- Patients with chronic hypertension.

- Known case of renal disease.

- Diabetes mellitus complicating pregnancy.

- Heart disease complicating pregnancy.

- Jaundice complicating pregnancy.

- Patients with urinary tract infection.

- Previous history of preeclampsia.

\section{Sample Size for Frequency in a Population}

Population size (For Finite Population Correction Factor or FPC) (N): 600 Hypothesized \% frequency of outcome factor in the population (p): $25 \%+/-5$ Confidence limits as $\%$ of 100 (absolute +/- \%) (d) : 5\%

Design Effect (For Cluster Surveys- DEFF): 1 Sample Size:

- $\quad \mathrm{N}=(\mathrm{Z}) 2[\mathrm{P}][\mathrm{l}-\mathrm{P}] / \mathrm{d} 2$

- Proportion of Preeclampsia- 0.25[25\%]

- $\quad(1.96) 2[0.25][0.75] /[0.05] 2=288[300]$

- Total no. of samples $=300$

\section{Sampling Method}

Purposive sampling.

Informed consent was obtained from each patient after explaining about my study. A detailed history was obtained regarding her name, age, height, pre-pregnancy weight, obstetric score, place of residence, socioeconomic class, past history of preeclampsia, family history suggestive of preeclampsia and associated comorbid conditions.

Her vitals were checked and basic investigations were done.

Patient's urine sample was collected and proteincreatinine ratio was estimated. Protein estimation was done using pyrogallol method, creatinine estimation was done by modified Jaffe's method and the ratio was obtained between the two.

Patients were advised to attend the antenatal clinic every two weeks. In her follow-up visit, she was examined thoroughly, especially her blood pressure and urine albumin was checked. Foetal well-being was assessed on each visit.

\section{Statistical Analysis}

For each variable, Mean + SD of all variables of interest were determined for preeclampsia cohort and for normal cohort separately and difference was tested by chi-square test.

The predictive values of urine protein-creatinine ratio was analysed using Pearson's ROC curve. Analysis was done by SPSS version 15. Comparison of variables was done using chi-square test.

\section{RESULTS}

The study group was grouped into two depending upon the development of preeclampsia as normal cohort and preeclamptic cohort.

The variables taken into consideration in this study are age group, obstetric score, socioeconomic class, prepregnancy weight, body mass index, urine spot proteincreatinine ratio value.

\begin{tabular}{|c|c|c|c|c|c|c|}
\hline & \multicolumn{6}{|c|}{ Cases } \\
\hline & \multicolumn{2}{|c|}{ Valid } & \multicolumn{2}{|c|}{ Missing } & \multicolumn{2}{|c|}{ Total } \\
\hline & No. & $\%$ & No. & $\%$ & No. & $\%$ \\
\hline $\begin{array}{l}\text { Age group } \\
\text { *occurrence of } \\
\text { preeclampsia }\end{array}$ & 300 & $100.0 \%$ & 0 & $.0 \%$ & 300 & $100.0 \%$ \\
\hline $\begin{array}{l}\text { Obstetric score* } \\
\text { occurrence of } \\
\text { preeclampsia }\end{array}$ & 300 & $100.0 \%$ & 0 & $.0 \%$ & 300 & $100.0 \%$ \\
\hline $\begin{array}{l}\text { Comorbid } \\
\text { conditions } \\
\text { *occurrence of } \\
\text { preeclampsia }\end{array}$ & 300 & $100.0 \%$ & 0 & $.0 \%$ & 300 & $100.0 \%$ \\
\hline $\begin{array}{c}\text { Se class } \\
\text { *occurrence of } \\
\text { preeclampsia }\end{array}$ & 300 & $100.0 \%$ & 0 & $.0 \%$ & 300 & $100.0 \%$ \\
\hline TS & & asso & edv & $\operatorname{tho}$ & & ef \\
\hline
\end{tabular}

\begin{tabular}{|c|c|c|c|c|}
\hline \multirow[b]{2}{*}{$\begin{array}{l}\text { Age Group } \\
\text { (yrs.) }\end{array}$} & \multicolumn{2}{|c|}{ Preeclamptic Cohort } & \multicolumn{2}{|c|}{ Normal Cohort } \\
\hline & $\begin{array}{l}\text { No. of } \\
\text { Cases }\end{array}$ & $\%$ & $\begin{array}{l}\text { No. of } \\
\text { Cases }\end{array}$ & $\%$ \\
\hline$<20$ & 9 & $42.9 \%$ & 14 & $5 \%$ \\
\hline $21-25$ & 4 & $19.0 \%$ & 176 & $63.1 \%$ \\
\hline $26-30$ & 0 & $0.0 \%$ & 67 & $24.0 \%$ \\
\hline 31 and above & 8 & $38.1 \%$ & 22 & $7.9 \%$ \\
\hline \multicolumn{5}{|c|}{$\begin{array}{c}\text { Table 2. Occurrence of Preeclampsia among various Age } \\
\text { Groups }\end{array}$} \\
\hline
\end{tabular}


- $\quad$ Chi-square $=65.652, \mathrm{p}=0.000$.

- Age group distribution showed $42.9 \%$ of preeclamptic cohort and $5 \%$ of normal cohort belonged to age group less than 20 years.

- In the age group of 31 and above, $38.1 \%$ developed preeclampsia-

- It indicates that preeclampsia is distributed and more common among teenage pregnancy and elderly gravida.

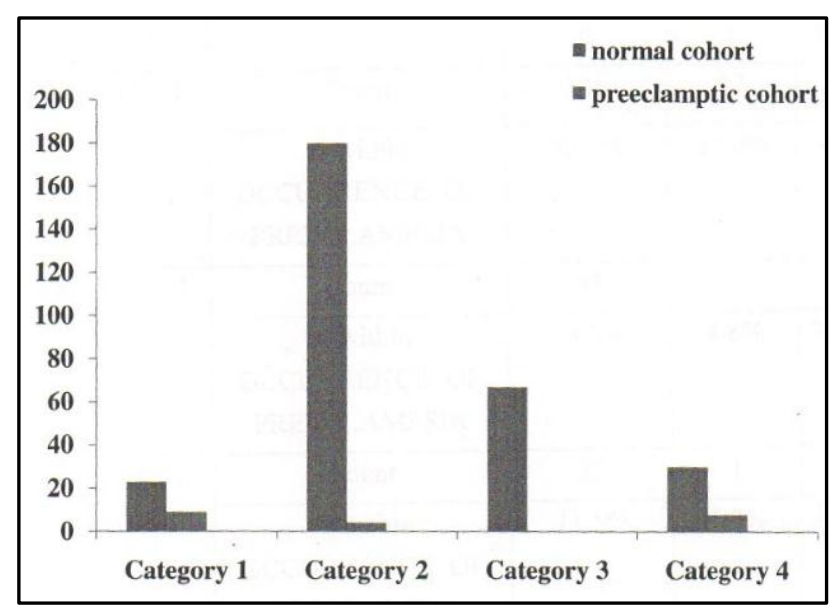

Figure 1. Age Group-Distribution among Study Population

\section{Inference}

As ' $p$ ' value is 0.000 , there is statistically significant difference between preeclamptic cohort and normal cohort with regard to age group.

\begin{tabular}{|c|c|c|c|c|c|}
\hline & \multicolumn{2}{|c|}{$\begin{array}{l}\text { Occurrence of } \\
\text { Preeclampsia }\end{array}$} & \multirow[b]{2}{*}{ Total } \\
\hline & & & $\mathbf{0}$ & 1 & \\
\hline \multirow{10}{*}{ 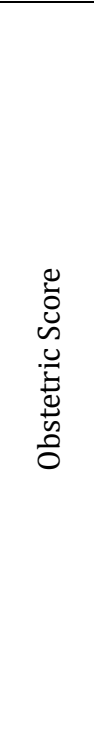 } & 1 & Count & 146 & 17 & 163 \\
\hline & & $\begin{array}{c}\% \text { within } \\
\text { occurrence of } \\
\text { preeclampsia }\end{array}$ & $52.3 \%$ & $81.0 \%$ & $54.3 \%$ \\
\hline & 2 & Count & 3 & 1 & 94 \\
\hline & & $\begin{array}{c}\% \text { within } \\
\text { occurrence of } \\
\text { preeclampsia }\end{array}$ & $33.3 \%$ & $4.8 \%$ & $31.3 \%$ \\
\hline & 3 & Count & 32 & 1 & 33 \\
\hline & & $\begin{array}{c}\% \text { within } \\
\text { occurrence of } \\
\text { preeclampsia }\end{array}$ & $11.5 \%$ & $4.8 \%$ & $11.0 \%$ \\
\hline & 4 & Count & 6 & 2 & 8 \\
\hline & & $\begin{array}{c}\% \text { within } \\
\text { occurrence of } \\
\text { preeclampsia }\end{array}$ & $2.2 \%$ & $9.5 \%$ & $2.7 \%$ \\
\hline & 5 & Count & 2 & 0 & 2 \\
\hline & & $\begin{array}{c}\text { \% within } \\
\text { occurrence of } \\
\text { preeclampsia }\end{array}$ & $.7 \%$ & $.0 \%$ & $.7 \%$ \\
\hline \multirow[t]{2}{*}{ Total } & & Count & 279 & 21 & 300 \\
\hline & & $\begin{array}{c}\% \text { within } \\
\text { occurrence of } \\
\text { preeclampsia }\end{array}$ & $100.0 \%$ & $100.0 \%$ & $100.0 \%$ \\
\hline \multicolumn{6}{|c|}{ Table 3. Obstetric Score-Occurrence of Preeclampsia } \\
\hline
\end{tabular}

Chi-square $=12.964, \mathrm{p}=0.011$.

\begin{tabular}{|c|c|c|c|c|}
\hline \multirow{2}{*}{ Parity } & \multicolumn{2}{|c|}{ Preeclamptic Cohort } & \multicolumn{2}{c|}{ Normal Cohort } \\
\cline { 2 - 5 } & $\begin{array}{c}\text { No. of } \\
\text { Cases }\end{array}$ & $\%$ & $\begin{array}{c}\text { No. of } \\
\text { Cases }\end{array}$ & $\%$ \\
\hline Primi & 17 & $81 \%$ & 146 & $52.3 \%$ \\
\hline Gravida 2 & 1 & $4.8 \%$ & 93 & $33.3 \%$ \\
\hline Gravida 3 & 1 & $4.8 \%$ & 32 & $11.5 \%$ \\
\hline Gravida 4 & 2 & $9.5 \%$ & 6 & $2.2 \%$ \\
\hline Gravida 5 & 0 & $0.0 \%$ & 2 & $0.7 \%$ \\
\hline
\end{tabular}

Table 4. Percentage distribution of Preeclampsia among Primigravida and Multigravida

This study indicates statistical significance between normal cohort and preeclamptic cohort.

Regarding parity, $81 \%$ of preeclampsia occurred in primigravida.

About $9.5 \%$ of preeclampsia occurred in fourth gravida, but it affected only $4.8 \%$ of gravida 2 and gravida 3 .

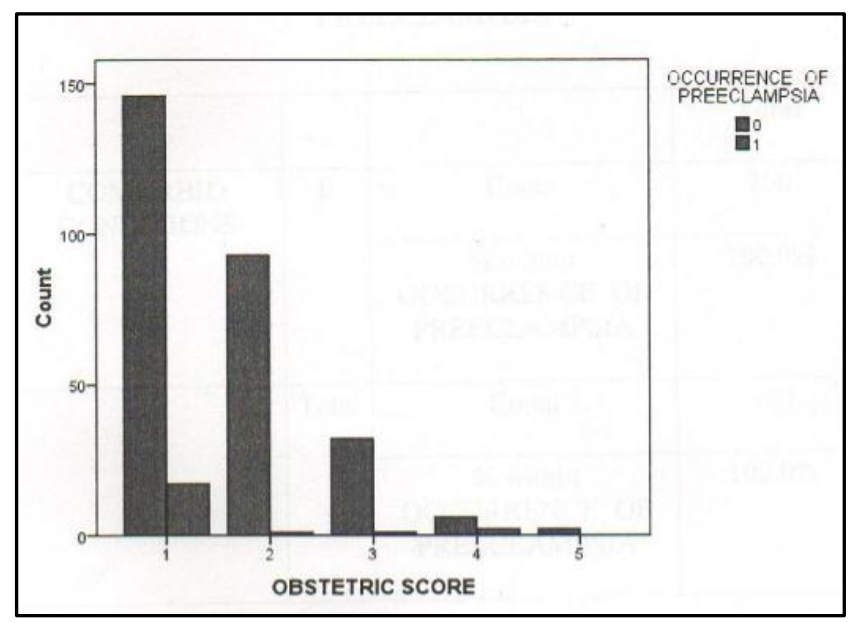

Figure 2. Obstetric Score- Distribution of Preeclampsia among Study Group

- $0=$ normal cohort, $1=$ preeclamptic cohort

Inference

\begin{tabular}{|l|c|c|c|}
\hline & & Count & Total \\
\hline \multirow{2}{*}{$\begin{array}{l}\text { Comorbid } \\
\text { Conditions }\end{array}$} & \multirow{2}{*}{0} & $\begin{array}{c}\text { \% within occurrence } \\
\text { of preeclampsia }\end{array}$ & $100.0 \%$ \\
\hline \multirow{2}{*}{ Table 5. Comorbid Conditions- Occurrence of } \\
Preeclampsia
\end{tabular}

Patients in the study group were selected without any comorbid conditions like chronic hypertension, renal disease, heart disease etc.

\begin{tabular}{|c|c|c|c|}
\hline & \multicolumn{2}{|c|}{$\begin{array}{l}\text { Occurrence of } \\
\text { Preeclampsia }\end{array}$} & \multirow[b]{2}{*}{ Total } \\
\hline & $\mathbf{0}$ & 1 & \\
\hline SE class 2 count & 1 & 0 & 1 \\
\hline $\begin{array}{c}\% \text { within occurrence of } \\
\text { preeclampsia }\end{array}$ & $.4 \%$ & $.0 \%$ & $.3 \%$ \\
\hline SE class 4 count & 91 & 5 & 96 \\
\hline $\begin{array}{c}\% \text { within occurrence of } \\
\text { preeclampsia }\end{array}$ & $32.6 \%$ & $23.8 \%$ & $32.0 \%$ \\
\hline SE class 5 count & 187 & 16 & 203 \\
\hline $\begin{array}{c}\% \text { within occurrence of } \\
\text { preeclampsia }\end{array}$ & $67.0 \%$ & $76.2 \%$ & $67.7 \%$ \\
\hline Count & 279 & 21 & 300 \\
\hline
\end{tabular}


About $67.7 \%$ of the pregnant women belonged to socioeconomic class 5 . Out of which, $76.2 \%$ developed preeclampsia and $67 \%$ belonged to normal cohort

\begin{tabular}{|c|c|c|c|c|}
\hline SE & \multicolumn{2}{|c|}{ Preeclamptic Cohort } & \multicolumn{2}{c|}{ Normal Cohort } \\
\hline Class & No. of Cases & \% & No. of Cases & \% \\
\hline 2 & 0 & $0.0 \%$ & $\underline{1}$ & $0.4 \%$ \\
\hline 4 & 5 & $24 . \mathrm{x} \%$ & 01 & $32.6 \%$ \\
\hline 5 & $\underline{\mathbf{1 6}}$ & $76.2 \%$ & $1 \times 7$ & $67.0 \%$ \\
\hline \multicolumn{3}{|c|}{ Table 7. SE Class- Occurrence of Preeclampsia } \\
\hline
\end{tabular}

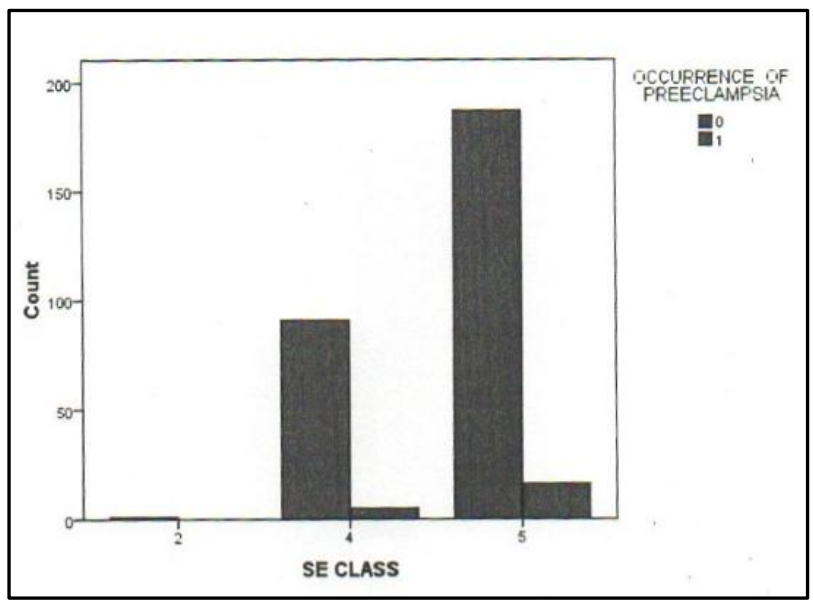

Figure 3. SE Class- Distribution of Preeclampsia

When SE class was taken into consideration, $67 \%$ of normal cohort and $76.2 \%$ of preeclamptic cohort occurred in the class 5 , whereas $32.6 \%$ of normal cohort and $23.8 \%$ of preeclamptic cohort belonged to class 4 SE class.

\section{Inference}

Since, the p-valve is 0.673 , there is no statistical significance between preeclamptic cohort and normal cohort with regard to socioeconomic class.

\begin{tabular}{|c|c|c|c|c|c|}
\hline & & & \multicolumn{3}{|c|}{$\begin{array}{l}\text { Occurrence of } \\
\text { Preeclampsia }\end{array}$} \\
\hline & & & 0 & 1 & Total \\
\hline \multirow{10}{*}{$\begin{array}{l}\text { BMI } \\
\text { Group }\end{array}$} & 1 & Count & 34 & 0 & 34 \\
\hline & & $\begin{array}{c}\text { \% within } \\
\text { occurrence of } \\
\text { preeclampsia }\end{array}$ & $12.2 \%$ & $.0 \%$ & $11.3 \%$ \\
\hline & 2 & Count & 128 & 2 & 130 \\
\hline & & $\begin{array}{c}\text { \% within } \\
\text { occurrence of } \\
\text { preeclampsia }\end{array}$ & $45.9 \%$ & $9.5 \%$ & $43.3 \%$ \\
\hline & 3 & Count & 96 & 7 & 103 \\
\hline & & $\begin{array}{c}\text { \% within } \\
\text { occurrence of } \\
\text { preeclampsia }\end{array}$ & $34.4 \%$ & $33.3 \%$ & $34.3 \%$ \\
\hline & 4 & Count & 16 & 10 & 26 \\
\hline & & $\begin{array}{c}\text { \% within } \\
\text { occurrence of } \\
\text { preeclampsia }\end{array}$ & $5.7 \%$ & $47.6 \%$ & $8.7 \%$ \\
\hline & 5 & Count & 5 & 2 & 7 \\
\hline & & $\begin{array}{c}\% \text { within } \\
\text { occurrence of } \\
\text { preeclampsia }\end{array}$ & $1.8 \%$ & $9.5 \%$ & $2.3 \%$ \\
\hline \multirow[t]{2}{*}{ Total } & & Count & 279 & 21 & 300 \\
\hline & & $\begin{array}{c}\% \text { within } \\
\text { occurrence of } \\
\text { preeclampsia }\end{array}$ & $100.0 \%$ & $100.0 \%$ & $100.0 \%$ \\
\hline \multicolumn{6}{|c|}{ Table 8. BMI Group-Occurrence of Preeclampsia } \\
\hline
\end{tabular}

Chi-square $=53.058, \mathrm{p}=0.0$

\begin{tabular}{|c|c|c|c|c|}
\hline \multirow{2}{*}{ BMI } & Preeclamptic Cohort & \multicolumn{2}{c|}{ Normal Cohort } \\
\cline { 2 - 5 } & No. of Cases & $\%$ & No. of Cases & $\%$ \\
\hline$<18.5$ & 0 & $0.0 \%$ & 34 & $12.2 \%$ \\
\hline $18.5-24.9$ & 2 & $9.5 \%$ & 128 & $45.9 \%$ \\
\hline $25-29.9$ & 7 & $33.3 \%$ & 96 & $34.4 \%$ \\
\hline $30-35$ & 10 & $47.6 \%$ & 16 & $5.7 \%$ \\
\hline $35-40$ & 2 & $9.5 \%$ & 5 & $1.8 \%$ \\
\hline \multicolumn{3}{|c|}{ Table 9. BMI- Occurrence of Preeclampsia } \\
\hline
\end{tabular}

- $\quad$ BMI of the study population was calculated according to her pre-pregnant weight.

- Quetelet index was used to calculate the BMI.

- From the above table it is clear that about $47.6 \%$ of preeclampsia occurred in the moderately obese group.

- $33.3 \%$ of preeclamptic cohort and $34.4 \%$ of normal cohort were present in overweight group.

- In women with normal BMI, preeclampsia occurred in 9.5\% and 45.9\% comes under normal cohort. My study population also included severely obese women and about $9.5 \%$ developed preeclampsia and $1.8 \%$ comes under normal cohort.

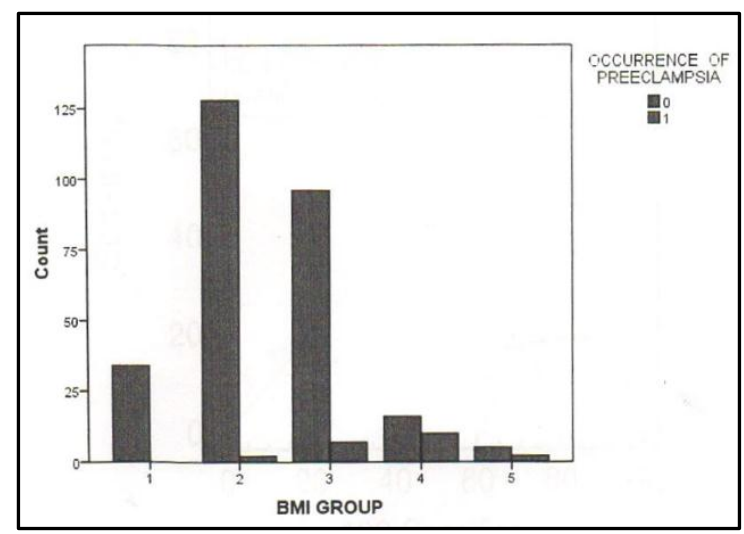

Figure 4. BMI-Distribution of Preeclampsia among Study Group

\section{Inference}

As $p=0.000$, there is statistical significance between preeclamptic cohort and normal cohort with regard to BMI.

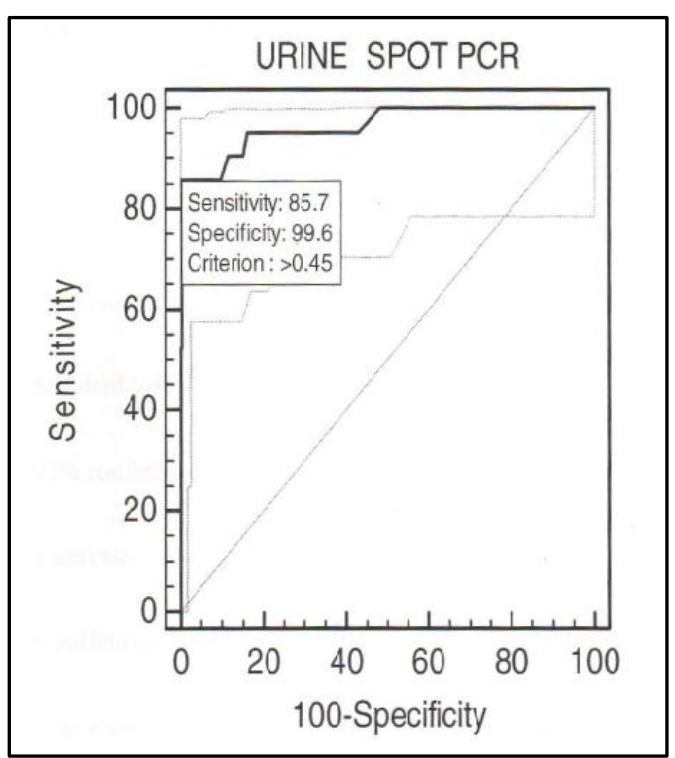

Figure 5. ROC Curve- Urine Spot Protein-Creatinine Ratio Urine Spot PCR 


\begin{tabular}{|c|c|c|c|}
\hline $\begin{array}{c}\text { Urine Spot } \\
\text { PCR }\end{array}$ & Total & $\begin{array}{c}\text { Preeclamptic } \\
\text { Cohort }\end{array}$ & $\begin{array}{c}\text { Normal } \\
\text { Cohort }\end{array}$ \\
\hline$>0.3$ & 21 & 18 & 3 \\
\hline $0.2-0.29$ & 54 & 2 & 52 \\
\hline$<0.2$ & 225 & 1 & 224 \\
\hline Table 10. Urine Spot PCR- Occurrence of Preeclampsia
\end{tabular}

\begin{tabular}{ll} 
Area under the ROC curve (AUC) & 0.964543 \\
Standard Error 4 & 0.0230 \\
95\% confidence interval & \\
Z statistic & 0.936806 to 0.982438 \\
Significance level P (Area $=0.5)$ & 20.192 \\
\hline C & $<0.0001$
\end{tabular}

The above table and ROC infer that there is a Good Fit in the prediction for the cut-off value $>0.45$ and the Area under the ROC curve (AUC) is 0.964543 . Sensitivity is 87.5 and specificity is 99.6. It indicates spot PCR is the good indicator for prediction of preeclampsia.
Area under a Receiver Operating Characteristic Curve (ROC)

Total area under ROC curve is used as a single index for measuring the performance of a test, when the AUC is larger the better is overall performance of the medical test to correctly identify diseased and non-diseased subjects. When the AUCs of two tests are equal it represents similar overall performance of tests, but this does not necessarily mean that both the curves are identical. It indicates that they may cross each other.

- Regarding urine spot PCR values, when the cut-off value is $>0.45$, the sensitivity is $85.71 \%$, specificity is $99.64 \%$.

- When the cut-off value is $>0.5$, the sensitivity of urine spot PCR is $76.19 \%$ and the specificity is the same (99.64\%).

- If the cut-off value is reduced to 0.2 , the sensitivity of the test increases to $95.24 \%$.

\begin{tabular}{|c|c|c|c|}
\hline & Occurrence of Preeclampsia & N & Mean \\
\hline \multirow{2}{*}{ Age (Yrs.) } & 1 & 21 & 24.71 \\
\cline { 2 - 4 } & 0 & 279 & 24.77 \\
\hline \multirow{2}{*}{ HT (CM) } & 1 & 21 & 152.48 \\
\cline { 2 - 4 } & 0 & 279 & 152.18 \\
\hline \multirow{2}{*}{ WT (KG) } & 1 & 21 & 69.14 \\
\cline { 2 - 4 } & 0 & 279 & 55.55 \\
\hline \multirow{2}{*}{ BMI } & 1 & 21 & 29.8481 \\
\cline { 2 - 4 } & 0 & 279 & 88.5271 \\
\hline Sample Taken & 1 & 21 & 18.00 \\
\hline GA (WKS) & 0 & 279 & 18.01 \\
\hline \multirow{2}{*}{ Urine Spot PCR } & 1 & 21 & .73 \\
\cline { 2 - 4 } & 0 & 278 & .12 \\
\hline
\end{tabular}

Table 11. Mean distribution of Preeclampsia among Various Variables

\begin{tabular}{|c|c|c|c|}
\hline & Occurrence of Preeclampsia & Std. Deviation & Std. Error Mean \\
\hline \multirow{2}{*}{ Age (Yrs.) } & 1 & 5.596 & 1.221 \\
\hline & 0 & 3.412 & .204 \\
\hline \multirow{2}{*}{$\mathrm{HT}(\mathrm{CM})$} & 1 & 5.810 & 1.268 \\
\hline & 0 & 6.175 & .370 \\
\hline \multirow{2}{*}{ WT (KG) } & 1 & 8.873 & 1.936 \\
\hline & 0 & 11.422 & .684 \\
\hline \multirow{2}{*}{ BMI } & 1 & 4.11899 & .89884 \\
\hline & 0 & 1078.18279 & 64.54912 \\
\hline \multirow{2}{*}{ Sample Taken GA(WKS) } & 1 & 1.549 & .338 \\
\hline & 0 & 1.373 & .082 \\
\hline Urine Spot PCR & 1 & .482 & .105 \\
\hline
\end{tabular}

From this study, it was found that the following variables are statistically significant

- Age of the patient.

- Obstetric score.

- Socioeconomic class.

- $\quad$ Prepregnancy weight of the patient and BMI.

- $\quad$ Urine spot protein-creatinine ratio.

\begin{tabular}{|c|c|c|}
\hline Variable & Chi-square Value & P \\
\hline Age Group & 65.652 & 0.000 \\
\hline Parity & 12.964 & 0.011 \\
\hline SE Class & 0.791 & 0.673 \\
\hline BMI & 53.058 & 0.000 \\
\hline \multicolumn{2}{|c|}{ Table 13. The Final Outcome of the Study }
\end{tabular}

Urine spot PCR with significant ' $\mathrm{P}$ ' $=<0.0001$.

\section{Summary}

From this study, it is found that there is statistical significance between preeclamptic cohort and normal cohort with regard to following variables-

- Age group,

- Obstetric score.

- Socioeconomic class.

- BMI.

- Urine PCR.

- When age group was taken into consideration, about 42.9\% developed.

- $\quad$ Preeclampsia and $5 \%$ did not develop preeclampsia in the age group $<20$ years. 
- In the age group $>30$ years, $38.1 \%$ developed preeclampsia and $7.9 \%$ did not develop preeclampsia. There was statistical significance between normal cohort and preeclamptic cohort.

- In my study, about $81 \%$ preeclampsia occurred in primigravida and only $4.8 \%$ occurred in gravida 2 and gravida 3.

- About 9.5\% of preeclamptic cohort and 2.2\% of normal cohort were present among gravida 4 .

- Among the people belonging to SE class 5, about $76.2 \%$ developed preeclampsia and $23.8 \%$ belonged to preeclamptic cohort in women belonging to SE class 4.

- There is no statistical significance with regard to SE class.

- About $47.6 \%$ of preeclamptic cohort were moderately obese patients. In my study group, preeclampsia did not occur in underweight persons.

- Only $9.5 \%$ of preeclampsia occurred in women with normal BMI and $33.3 \%$ in overweight individual. The variable BMI is also statistically significant.

- The cut-off value for urine PCR was taken as $>0.45$ to predict preeclampsia with $85.71 \%$ sensitivity and $99.64 \%$ specificity. When the cut-off value is reduced, the sensitivity increases.

- The area under the ROC curve, for urine PCR is 0.964 .

\section{DISCUSSION}

- Our study population included 300 antenatal women who attended antenatal outpatient department. Among them, urine spot PCR predicted preeclampsia in 21 patients.

- Out of 21 patients 18 women had urine spot PCR, cut-off value $>0.45$.

- Only 2 patients developed preeclampsia in the cut-off value between 0.2 and 0.29 .

- In the cut-off value $<0.2$, only one patient developed preeclampsia.

- It was also found that preeclampsia is more common among women with increased pre-pregnant weight and $\mathrm{BMI}>25$.

- Our study also reported that primigravida and age group less than 20 years were more prone to develop preeclampsia.

- Our study is supported by the analysis done by Laleh Eslamian, Fariba Behnam, Zahra Foroohesh Tehrani, Ashraf Jamal and Vajiheh Marsoosil (26 Apr. 2009;). The study showed a cut-off value of $0.22 \mathrm{mg} / \mathrm{mg}$ for proteincreatinine ratio and it best predicted significant proteinuria with sensitivity, specificity, positive and negative predictive values of $87 \%, 92.6 \%, 90.6 \%$ and 89.3\% respectively.(8)

- Amita Sharma, Pandey Kiran, Bhagoliwal Ajai (3 August 2013); Spot urine $\mathrm{P} / \mathrm{C}$ ratio and the 24-hour urine protein was measured.(9)

- They found that there was a strong correlation between the spot $\mathrm{P} / \mathrm{C}$ ratio and 24-hour urine-protein excretion (Pearson's correlation coefficient $r=0.71 ; \mathrm{P}<0.0001$ ).
- The optimal cut-off point of spot $\mathrm{P} / \mathrm{C}$ ratio was 0.25 , for $300 \mathrm{mg} / 24 \mathrm{~h}$ of protein excretion with sensitivity and specificity of $69 \%$ and $75 \%$ respectively. ${ }^{(9)}$

\section{CONCLUSION}

After Investigating and Analysing the Study, it was found that-

- Urine spot PCR is a simple method and rapid test to predict preeclampsia. When cut-off value is more, the specificity increases.

- From this study it is concluded that, when the cut-off value for urine spot PCR is $>0.45$, the sensitivity is $85.71 \%$ and specificity is $99.64 \%$.

- Urine spot PCR can be used to predict preeclampsia in early gestation itself, so that the patient can be kept under proper surveillance with more frequent antenatal check-up and to detect the complications earlier to prevent maternal and foetal morbidity and mortality.

- Urine spot PCR can be used at the level of primary health centre, to detect the high-risk pregnancies and refer them to the tertiary care centre at the earliest.

- It was also found that more number of preeclampsia occurred in women with increased pre-pregnancy weight with raised BML overweight and obese women developed preeclampsia more than the normal individual; therefore, proper weight reduction will reduce the risk of developing preeclampsia.

- Urine spot PCR can be used to predict preeclampsia with a single random midstream urine sample when compared to $24 \mathrm{hrs}$. urine-protein estimation and routine dipstick method.

\section{REFERENCES}

[1] Shahbazian N, Hosseini-Asl F. A comparison of spot urine protein-creatinine ratio with 24- hour urine protein excretion in women with preeclampsia. IJKD 2008;2(3):127-31. www.ijkd.org

[2] Sibai BM, Gordon T, Thom E, et al. Risk factors for preeclampsia in healthy nulliparous women: a prospective multicenter study. The National Institute of Child Health and Human Development Network of Maternal-Fetal Medicine Units. Am J Obstet Gynecol 1995;172(2 Pt 1):642-8.

[3] Chesley LC. Hypertensive disorders in pregnancy. Williams Obstetrics 14th edn. New York: Appleton Century Crofts 1971: p. 700.

[4] Uzan J, Carbonnel M, Piconne O, et al. Pre-eclampsia: pathophysiology, diagnosis and management. Vasc Health Risk Manag 2011;7:467-74.

[5] Sethuram R, Kiran TS, Weerakkody AN. Is the urine spot protein/creatinine ratio a valid diagnostic test for pre-eclampsia? J Obstet Gynaecol 2011;31(2):128-30.

[6] Chhabra S, Singh A. Maternal morbidity with early onset hypertensive disorders during pregnancy. Journal Gynaecology \& Reproductive Endocrinology 2017;1(1):21-7.

[7] Report of the National High Blood Pressure Education Program Working Group on high blood pressure in pregnancy. Am J Obstet Gynecol 2000;183(1):S1-S22. 


\section{Jemds.com}

[8] Eslamian L, Behnam F, Tehrani ZF, et al. Random urine protein creatinine ratio as a pre admission test in hypertensive pregnancies with urinary protein creatinine ratio. Acta Med Iran 2011;49(2):81-4.

\section{Original Research Article}

[9] Sharma A, Kiran P, Ajai B. Spot urine protein creatinine ratio - a quick and accurate method for diagnosis of pre eclampsia. OJOG 2013;3(8):609-12. Doi:10.4236/2013.38109. 